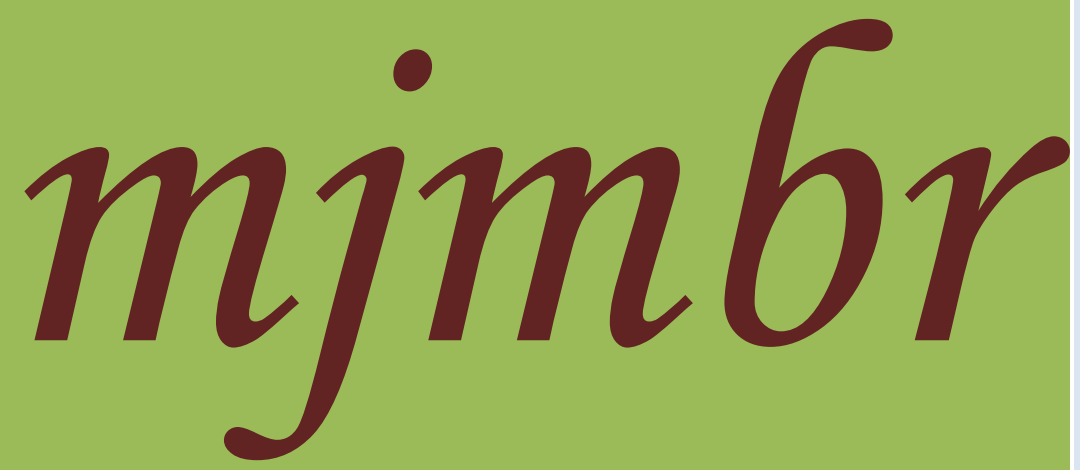

Malaysian Journal of Medical and Biological Research

www.jmbr-my.weebly.com

Vol 1, No. 1, 2014 


\title{
Fish Culture Practice and Socio Economic Status in Northern Middle Part of Bangladesh
}

\author{
Samir Kumer Sarker ${ }^{1}$, Md. Tawheed Hasan ${ }^{2}$, Simon Kumar Das ${ }^{3}$, \& \\ Sabuj Kanti Mazumder ${ }^{4}$
}

${ }^{1}$ Quality Assurance Officer, BEST Project, Upazilla Fisheries Office, Satkhira, Bangladesh

${ }^{2}$ Lecturer, Departemt of Aquaculture, Sylhet Agricultural University, Bangladesh

${ }^{3}$ Senior Lecturer, School of Environmental and Natural Resource Sciences, UKM, Malaysia

${ }^{4}$ Assistant Professor, Dept. of Aquatic Resource Management, Sylhet Agricultural University, Bangladesh

\begin{abstract}
The present study was carried out in Bhaluka upazilla, the northern middle part of Bangladesh to observe the culture technique of fish culture using of supplementary feeds and socio-economic condition of the fish farm owners. Data were collected from 39 fish farms in Bhaluka upazilla during the period from September 2010 to August 2011. Most of the studied farm owners carried out polyculture system and culture, mostly carps (Indian major carps and exotic carps), pangus and tilapia using supplementary feeds. The feeding rate varied from $1-7 \%$ of body weight of fish with frequency $1-3$ times/day. The highest production was recorded as $56,810 \mathrm{~kg} / \mathrm{ha} / \mathrm{yr}$ using company feed and the lowest production was recorded as $14,210 \mathrm{~kg} / \mathrm{ha} / \mathrm{yr}$ with an average production of $34,350 \mathrm{~kg} / \mathrm{ha} / \mathrm{yr}$. The average production of $23,520 \mathrm{~kg} / \mathrm{ha} / \mathrm{yr}$ was recorded (farm made feed). Most of the farmers did not use fertilizer and manure in their ponds, but in winter season sometimes they used poultry litter to avoid high priced feed. The overall management practice was not smoothly developed in the monoculture and polyculture farms. It may be concluded that we have to reduce all of the constraints of management practices of aquaculture to achieve sustainable growth in future aquaculture of Bangladesh.
\end{abstract}

Key words: Beel, Fish farm, Owner, Stocking density and fry

\section{INTRODUCTION}

Bangladesh is an agro-based riverine country enriched with vast fisheries resources. It lies in the north-eastern part of the South Asia, between $20^{\circ} 34^{\prime}$ and $26^{\circ} 38^{\prime}$ north latitude and $88^{\circ} 01^{\prime}$ and $92^{\circ} 41^{\prime}$ east longitude. The country is surrounded by India on the west, the north and the northwest and Myanmar on the southeast and the Bay of Bengal on the south. Its total area is covering $147,570 \mathrm{sq}$. km. Fish and Fisheries play a significant role in the economy of Bangladesh in terms of nutrition, income, employment and earning foreign exchange. Bangladesh is a highly populated country. The total population of this country is about 142,319 thousand (BBS, 2011). So the nutrition requirement is very high in our country. Fish is the principal source of animal protein for the people of Bangladesh. 
Fish provides about $60 \%$ animal protein for the people of Bangladesh. Fisheries sector is contributing about $3.74 \%$ to GDP and 3.00\% to nation's foreign exchange (DoF, 2010). There are about 12.5 million people's livelihood depends directly and indirectly on the fisheries sector.

Bangladesh is very rich in inland capture fish production. But now-a-days capture fish production is decreasing day by day due to different causes. Such as agricultural pollution, industrial pollution, natural calamity etc. Fish of the beels along with other aquatic organisms are silent victims of chlorine sub-lethal toxicity resulting from different types of pollutants matters (Bernet et.al., 1999). Fish production is also decreasing due to natural causes like flood, drought etc. (Chakraborty 2009). So due to high demand of fish its needs to increase culture based fishery in the country. There are about 265 indigenous species and 12 exotic species of fish, 24 species of prawn and 36 species of shrimp (DoF, 2010). Above these species some are used as culture species. The commercially important culture species are Rui, Catla, Mrigal, Bighead carp, Mirror carp, Minor carp, Silver carp, Sharpunti, Tilapia, Pangas, Thai koi, Shing, Magur etc.

In Bangladesh fish culture is very popular mostly in Bhaluka upazila, the northern middle part of Bangladesh. About $80 \%$ people of Bhaluka upazila engage with agricultural activities. Due to the environmental suitability and the economic profit fish culture is increasing very rapidly. The soil, water and climate are very much suitable for aquaculture in Bhaluka upazila. The temperature ranges from 7 to $36^{\circ} \mathrm{C}$ (BBS, 2011). That is very essential for the fish culture. But the management practice is not maintained properly. They practiced fish culture with very high stocking density and used different types of supplementary feeds to get the more production. Most of the farmers of this area thought about the production, but never think about the management practice. In the Bhaluka upazilla there are many large water bodies known as beel. The management technique of these water bodies is very simple. Different farmers used poultry manure in their water bodies, but they have no idea about the effects of poultry manure in water bodies. Taking all the issues in concern the present study is conducted with a view to serve the following objectives- 1 . To know the socioeconomic status of the fish farm owners; 2 . To observe the management technique of fish culture; 3 . To know the water quality parameters of the existing culture system and 4 . To find out a suitable methods of feeding rate and use of quality feed for more production of fish.

\section{MetHodology}

\section{Profile of the study area}

The study was conducted in Bhaluka Upazilla lies between $24^{\circ} 38^{\prime \prime} \mathrm{N}$ and $91^{\circ} 33^{\prime \prime} \mathrm{E}$ situated in Mymensing District in Dhaka Division Bangladesh (Figure 1). The total area of Bhaluka Upazilla is $444.05 \mathrm{sq} \mathrm{km}$. and water area is 9026ha. Most of the area was related to fish culture. The topography is irregular. The soil type of these water bodies is loams to clay loams. The color of the soil is grey to brownish. The northern side of the upazilla is bounded by Fulbaria and Trisal upazilla and eastern side is Gaffargoan upazilla under the Mymensingh district. The southern side attached with Sreepur Upazilla under Gazipur district and the western side is covered by Sakhipur and Ghatail upazilla under the Tangail district. Main rivers of the upazilla are Khiru and Sutia (Fig. 1). 


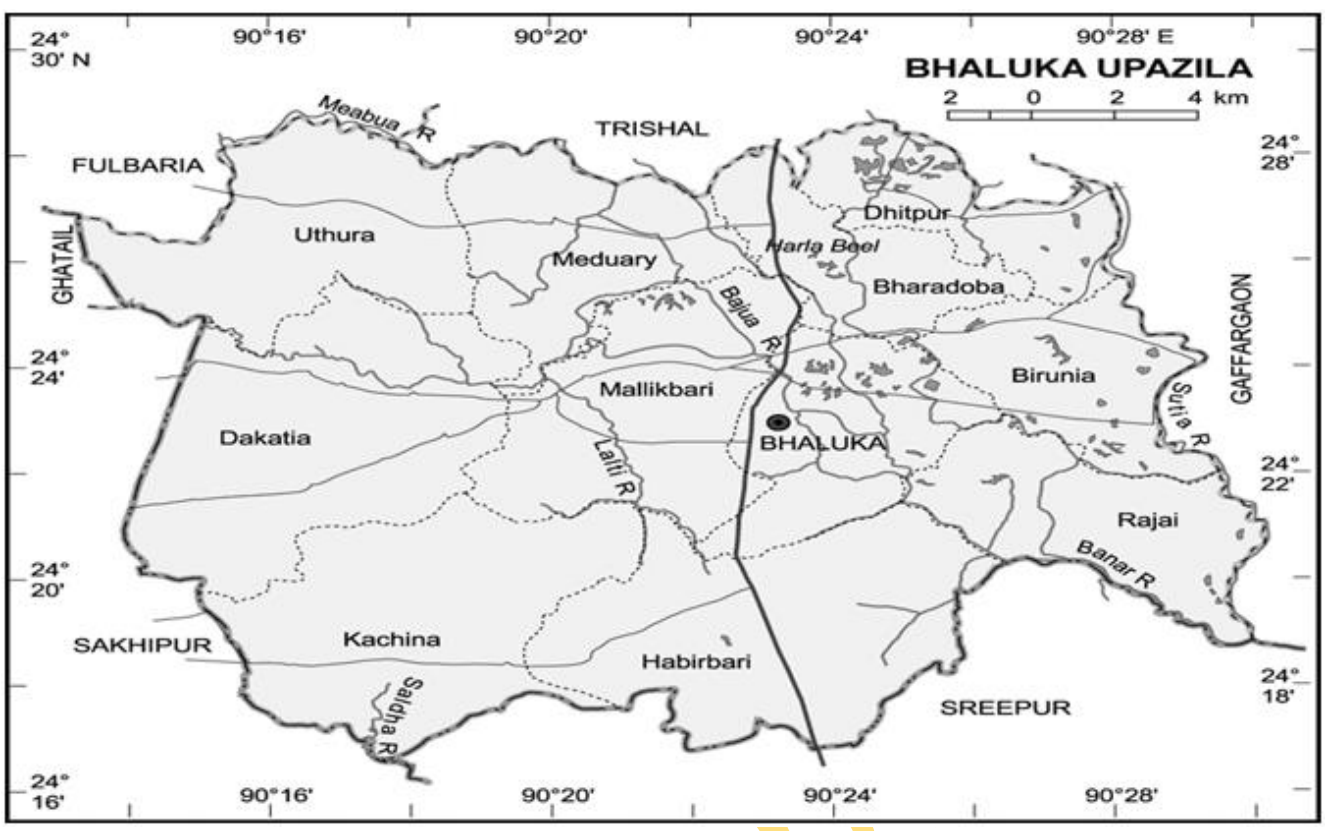

Figure 1: map of Bhaluka Upazilla

\section{Questionnaire preparation and data collection}

On the basis of objectives the questionnaire was made to consist of all necessary questions that were essential for detail information about the farm. The questionnaire has the two parts, one is personal information and another is farm information. Then the schedule was pre-tested to verify the relevance of the questions and the nature of the sample producers. After pre-testing and necessary adjustment, a final survey schedule was developed. For the interest of study 3 categories (small, medium and large farms) of farm was selected in the different area of Bhaluka upazilla.

The data were collected for the period of 12 months between September 2010 to August 2011 in Bhaluka upazilla, Bangladesh. The selected number of fish farmer was 39. A random sampling technique was followed to select the location of the different farm. The direct monitoring was conducted frequently for the accurate information about the fish culture. The essential information was noted during interview. The questions were asked to the farmers very systematically. The explanations of the farmers are recorded in the questionnaire. For the each respondent a set of questionnaire was prepared.

\section{Processing and analysis of data}

The collected data were summarized, tabulated and analyzed according to the objectives of the study. The data were analyzed through one way ANOVA using SPSS and Excel followed to find out whether any significant difference was existed among different studies (Duncan, 1955; Zar, 1984). 


\section{RESULTS}

\section{Socio-economic characteristics of the fish farm owners}

Out of 39 farm owners the highest level of the total farm owners were belonged to the age group range of $20-30$ years $(35 \%)$ and the lowest level farm owners were belongs to age group range $51-60$ years (15\%) and other $30 \%$ and $20 \%$ were age group ranges between $31-$ 40 and 41-50 years respectively. In the case of educational status, $12 \%$ of the total man's power are illiterate but had the ability of signature. About $70 \%$ of the man's power had primary and high school education. About $14 \%$ manpower of the farm had SSC to HSC level and other $4 \%$ had a Graduate level education. The occupation of the fish farm owners is divided into four groups. The highest percentage was found in group fish farm and agriculture (35.90\%) whereas the lowest was in group fish farm and job (Table 1 ).

Table I: Occupation status of the fish farm owners of the studied area.

\begin{tabular}{lccccc}
\hline \multicolumn{1}{c}{ Type of occupation } & $\begin{array}{c}\text { Monoculture } \\
(\mathbf{N = 0 8 )}\end{array}$ & $\begin{array}{c}\text { Polyculture } \\
\mathbf{( N = 3 1 )}\end{array}$ & $\begin{array}{c}\text { Total Farm } \\
\text { (n) }\end{array}$ & $\begin{array}{c}\text { Percentage } \\
\text { (\%) }\end{array}$ & $\begin{array}{c}\text { Cumulative } \\
\text { (\%) }\end{array}$ \\
\hline Only Fish farm business & 2 & 10 & 12 & 30.76 & \\
Fish farm + Job & 3 & 6 & 9 & 23.08 & 53.84 \\
Fish farm + Agriculture & 2 & 12 & 14 & 35.90 & 89.74 \\
Fish farm + Others & 1 & 3 & 4 & 10.26 & 100 \\
\hline
\end{tabular}

About $8 \%$ Owners mentioned that the transportation facilities of farm was not good due to narrow road, $62 \%$ mentioned as good, while $30 \%$ owners mentioned the facility as excellent.

Farmers were trained from the different organization. Out of 39 fish farm owners 20.51\% had no training while 30.77\% received training from BFRI, Department of Fisheries (DoF) and NGO's. About $48.72 \%$ owners gained their knowledge on fish farm operation through personal contact. The farm owners receive technical assistance from DoF and other organizations. Local people were benefited from fish farm through various ways. It was found that the benefits were employment opportunity, poverty alleviation, increased consumption of fish and socio-economic status (Table 2).

Table II: Percentage distribution fish farms given benefit to people

\begin{tabular}{lcc}
\hline \multicolumn{1}{c}{ Benefit } & Number of cases $\mathbf{( N = 3 9 )}$ & Percentage \\
\hline Employment opportunity & 14 & 35.89 \\
Poverty alleviation & 11 & 28.22 \\
Increased consumption of fish & 08 & 20.51 \\
Obtain their money through leasing & 06 & 15.38 \\
\hline
\end{tabular}

\section{Feature of the water body}

Both monoculture and polyculture were practiced in Bhaluka upazilla but polyculture practice is very advanced. During the study period it seems that about $79.5 \%$ was found in polyculture and $20.5 \%$ was in monoculture. The area of fish farms of the study area was classified into three categories that are Small $(<1.00)$, Medium (1.1-3.00) and Large $(3.1>)$ ha. Out of 39 farms $38.5 \%$ were in small categories, $33.3 \%$ were in medium categories and rest of the farms $28.2 \%$ were in large categories (Table 3 ).

Table III: Farm size and their frequencies in the study area.

\begin{tabular}{|c|c|c|c|c|c|}
\hline \multirow{2}{*}{$\begin{array}{c}\text { Area } \\
\text { (ha) }\end{array}$} & \multicolumn{2}{|c|}{ Number of different fish farms } & \multirow{2}{*}{$\begin{array}{c}\text { Total fish farms } \\
(\mathrm{N}=39)\end{array}$} & \multirow{2}{*}{$\begin{array}{c}\text { Percentage } \\
(\%)\end{array}$} & \multirow{2}{*}{$\begin{array}{c}\text { Cummulative } \\
(\%)\end{array}$} \\
\hline & Monoculture $(\mathrm{N}=08)$ & Polyculture $(\mathrm{N}=31)$ & & & \\
\hline Small (>1.00) & 03 & 12 & 15 & 38.5 & 00 \\
\hline Medium (1.1-3.00) & 03 & 10 & 13 & 33.3 & 71.8 \\
\hline Large $(3.1<)$ & 02 & 9 & 11 & 28.2 & 100 \\
\hline
\end{tabular}


In the studied area, 30\% of farm owners having single ownership, 15\% having multiple ownership and 55\% having leased water body (Figure 2).

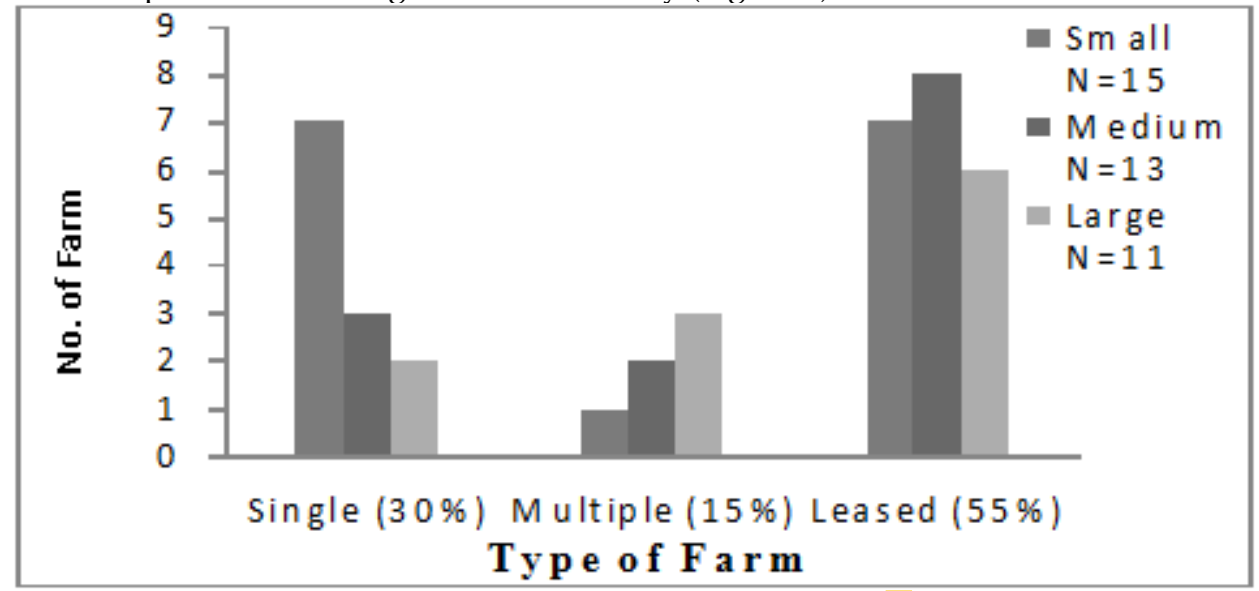

Figure 2: Showing ownership of the water body in the study area.

In the study area about $80 \%$ of the water bodies were irregular shaped due to tectonic origin and $20 \%$ water bodies were regular shaped. The minimum size of the pond is 0.16 ha and the maximum size of the pond is 37.24 ha where as average pond size was 5.78 ha. The depth of the water body varies from summer to winter. The average depth of the water body in winter season was $1.61 \pm 0.15$ meter and in summer season was $2.32 \pm 0.15$ meter.

The farmers were commonly used shallow and deep tube wells. About $74.36 \%$ farm owners had Shallow tube well, 20.52\% farm owners had Deep tube well and only $5.12 \%$ farm owners usually depended on the rainfall (Table 4).

Table IV: Source of water in the respective fish farm

\begin{tabular}{lcccc}
\hline Sources of water & $\begin{array}{c}\text { Number of Different farms } \\
\text { Monoculture N=08 }\end{array}$ & $\begin{array}{c}\text { Total N=39 } \\
\text { Polyculture N=31 }\end{array}$ & Percentage (\%) & \\
\hline Shallow tube well & 7 & 22 & 29 & 74.36 \\
Deep tube well & 1 & 7 & 8 & 20.52 \\
Rain fall & 0 & 2 & 2 & 5.12 \\
\hline
\end{tabular}

\section{Water quality parameter}

The water quality parameters like water temperature, transparency, $\mathrm{pH}$, dissolved oxygen were measured to know whether it is suitable or not (Table 5).

Table V. Water quality parameters of the farms in the study areas.

\begin{tabular}{lccc}
\hline \multicolumn{1}{c}{ Parameters } & Small farm & Medium farm & Large farm \\
\hline \multirow{2}{*}{ Temperature $\left({ }^{\circ} \mathrm{C}\right)$} & $25.98 \pm 4.26$ & $25.94 \pm 5.06$ & $25.81 \pm 7.14$ \\
& $(14.01-32.40)$ & $(14.15-32.40)$ & $(14.20-31.40)$ \\
\hline \multirow{2}{*}{ Transparency $(\mathrm{cm})$} & $28.48 \pm 2.79$ & $29.30 \pm 3.64$ & $36.24 \pm 4.61$ \\
& $(23.80-37.50)$ & $(25.40-41.40)$ & $(24.10-45.20)$ \\
\hline \multirow{2}{*}{$\mathrm{pH}$} & $8.45 \pm 0.30$ & $8.08 \pm 0.33$ & $8.17 \pm 0.35$ \\
& $(7.70-8.40)$ & $(7.80-8.60)$ & $(7.70-8.55)$ \\
\hline \multirow{2}{*}{ Dissolved oxygen $\left(\mathrm{mg} . \mathrm{L}^{-1}\right)$} & $4.72 \pm 0.66$ & $4.47 \pm 0.70$ & $4.05 \pm 0.88$ \\
& $(3.80-6.12)$ & $(3.50-6.10)$ & $(3.20-5.43)$ \\
\hline
\end{tabular}




\section{Management of fish culture}

Pre-stocking management

About $90 \%$ fish farmers dried their ponds 2-4 year's interval. But rest of others dried their ponds $4-5$ year's interval because the very large water body. $84 \%$ farmer used lime in their pond. The dose of lime varies from $0.25 \mathrm{~kg} / \mathrm{dec}$. to $1.50 \mathrm{~kg} / \mathrm{dec}$. About $55 \%$ farmers don't use fertilizer and manure in their water bodies. They used compost as a fertilizer and in some cases used poultry litter in their pond. About $80 \%$ farm owners knew it was harmful for aquatic environment but they used it for the save of feed cost. The dose of the poultry litter was indiscriminate.

\section{Stocking management}

The maximum fish farm owner used fry in their fish culture farm. At first the fry are stocked in the nursing pond. After nursing, the fingerlings are stocked in the culture pond. The highest size of the pangus and bangla fish were 3-4 inch and the tilapia was $1.5 \mathrm{inch}$. It was found that higher density of pangus, tilapia and indian major carps were maintained in the farms of Bhaluka Upazilla (Table 6).

Table VI: Stocking density of fry in monoculture and polyculture systems in the study area.

\begin{tabular}{ccccc}
\hline Stocking density (No/ha) & Monoculture (N=08) & Percentage (\%) & Polyculture (N=31) & Percentage (\%) \\
\hline $50,000-75,000$ & 6 & 75 & 2 & 6.45 \\
$75,001-1,00,000$ & 1 & 12.5 & 1 & 3.22 \\
$1,00,001-1,25,000$ & 1 & 12.5 & - & - \\
$1,25,001-1,50,000$ & - & - & 4 & 12.91 \\
$1,50,001-175,000$ & - & - & 6 & 19.35 \\
$1,75,001-2,00,000$ & - & - & 1 & 3.22 \\
$2,00,001-2,25,000$ & - & - & - & - \\
$2,25,001-2,50,000$ & - & - & 2 & 6.45 \\
$2,50,001-2,75,000$ & - & - & 4 & 12.91 \\
$2,75,001-3,00,000$ & - & - & 5 & 16.13 \\
$3,00,001-3,25,000$ & - & - & - & - \\
$3,25,001-3,50,000$ & - & - & - & - \\
$3,50,001-3,75,000$ & - & - & 4 & 12.91 \\
$3,75,001-4,00,000$ & - & & 2 & 6.45 \\
\hline
\end{tabular}

Post-stocking management

In the studied area, about $5.12 \%$ monoculture and $17.96 \%$ polyculture farm owners sampled weekly, $7.69 \%$ and $20.51 \%$ farm owners sampled fortnightly, $5.12 \%$ and $25.65 \%$ farm owner sampled monthly and $2.56 \%$ and $15.39 \%$ farm owner sampled irregularly. $90 \%$ farm used supplementary ready made feed and rest of $10 \%$ farm owner used home made feed. The different types of company supplied feeds in the farms. They don't maintain actual feed ingredients. Farm owner used Saudi Bangla fish feed, Mega feed, ACI fish feed, CP, Biswas fish feed, Aftab fish feed etc. Farmers used two types of fish feed; sinking feed and floating feed. The cost of supplementary man made feed were range to be 22.0 to $23.0 \mathrm{BDT}$. $/ \mathrm{kg}$ and the price of company ready made floating and sinking feeds were found to be 25.0 to33.0 BTK $/ \mathrm{kg}$ (Table 7).

Table VII: Commercial supplementary feed used in different fish farms of the study area

Company Name User percentage (\%) Price/Bag (BDT)

\begin{tabular}{lcc}
\hline ACI fish feed & 10.28 & 680 \\
Saudi Bangla fish feed & 12.85 & 800 \\
Mega fish feed & 17.95 & 820 \\
Aftab fish feed & 7.70 & 740 \\
CP fish feed & 5.12 & 750 \\
National fish feed & 7.70 & 720 \\
Fresh fish feed & 10.28 & 660 \\
Quality fish feed & 7.70 & 650 \\
Biswas fish feed & 10.28 & 650 \\
\hline
\end{tabular}


In monoculture practice feeding rates were found to be $5-6 \%$ and $6-7 \%$ of fish body weight for small fish, $1-2 \%$ and $2-3 \%$ for large fish. In polyculture feeding rates were found to be $5-6 \%$ and $6-7 \%$ of fish body weight for small fish, $1-2 \%$ and $2-3 \%$ for large fish. $35.89 \%$ farmer used feeding frequency 1 time/day, 53.85\% used 2 times/day and $10.26 \%$ used 3 times/day, respectively (Table 8).

Table VIII: Feeding frequency of the farms

\begin{tabular}{|l|c|c|c|c|}
\hline \multirow{2}{*}{ Feeding frequency } & Monoculture & Polyculture & \multirow{2}{*}{ Total Number } & \multirow{2}{*}{ Percentage (\%) } \\
\cline { 2 - 3 } & $\mathbf{N = 0 8}$ & $\mathbf{N = 3 1}$ & & \\
\hline 1 time/day & 3 & 11 & 14 & 35.89 \\
\hline 2 times/day & 4 & 17 & 21 & 53.85 \\
\hline 3 times/day & 1 & 3 & 4 & 10.26 \\
\hline
\end{tabular}

In monoculture practice, farm owners harvest the fish yearly in a culture period and in poly culture system harvesting was practiced two to four times yearly. Among 31 polyculture farms $67.75 \%$ had done partial harvesting.

\section{Fish production}

In case of man made feed, the highest production was recorded at $31,820 \mathrm{~kg} / \mathrm{ha} / \mathrm{yr}$ where lowest production was found to be $10,157 \mathrm{~kg} / \mathrm{ha} / \mathrm{yr}$ with an average production of 23,520 $\mathrm{kg} / \mathrm{ha} / \mathrm{yr}$. On the other hand, in case of company feed the highest production was recorded at $56,810 \mathrm{~kg} / \mathrm{ha} / \mathrm{yr}$ and the lowest production was $14,210 \mathrm{~kg} / \mathrm{ha} / \mathrm{yr}$ with an average production of $34,350 \mathrm{~kg} / \mathrm{ha} / \mathrm{yr}$ (Table 9 ).

Table IX: Fish production in the study area.

\begin{tabular}{cccc}
\hline Feed & $\begin{array}{c}\text { Highest production } \\
\mathbf{( k g} / \mathbf{h a} / \mathbf{y r})\end{array}$ & $\begin{array}{c}\text { Lowest Production } \\
\mathbf{( k g / h a / y r )}\end{array}$ & Average \\
\hline Farmmade feed & 31,820 & 10,157 & 23,520 \\
Company feed & 56,810 & 14,210 & 34,350 \\
\hline
\end{tabular}

\section{Feed Ingredients analysis}

The different types of feed used in the Bhaluka upazilla were analyzed. Proximate composition of the feeds was analyzed according to AOAC (1995) method, nitrogen free extract (NFE) by subtraction. Daily ration was adjusted by estimating of standing crop once weekly, fortnightly and monthly (Table 10).

Table X: Analyzed proximate composition $( \pm$ SE) of different types feed.

\begin{tabular}{|c|c|c|c|c|c|c|c|c|}
\hline \multirow{2}{*}{ Type of the Feed } & \multicolumn{2}{|c|}{ Moisture } & \multicolumn{2}{|c|}{ Lipid } & \multicolumn{2}{|c|}{ Protein } & \multicolumn{2}{|c|}{ Ash } \\
\hline & Range & Mean & Range & Mean & Range & Mean & Range & Mean \\
\hline $\begin{array}{l}\text { Abdul Mannan farm } \\
\text { made feed }\end{array}$ & $16.33-17.27$ & $\begin{array}{l}16.83 \\
\pm 0.27 \\
\end{array}$ & $9.26-14.06$ & $\begin{array}{l}11.79 \\
\pm 1.39 \\
\end{array}$ & $21.13-25.63$ & $\begin{array}{l}23.70 \\
\pm 1.33 \\
\end{array}$ & $11.40-13.40$ & $\begin{array}{l}12.67 \\
\pm 0.63 \\
\end{array}$ \\
\hline $\begin{array}{l}\text { Md. Suruj Mia farm } \\
\text { made feed }\end{array}$ & $11.11-13.48$ & $\begin{array}{l}12.51 \\
\pm 0.71 \\
\end{array}$ & $8.94-12.94$ & $\begin{array}{l}10.47 \\
\pm 1.24 \\
\end{array}$ & $21.12-27.05$ & $\begin{array}{l}24.57 \\
\pm 1.78 \\
\end{array}$ & $13.42-17.20$ & $\begin{array}{l}15.44 \\
\pm 1.10 \\
\end{array}$ \\
\hline $\begin{array}{l}\text { Md.Azad farm made } \\
\text { feed }\end{array}$ & $15.68-25.75$ & $\begin{array}{l}19.36 \\
\pm 3.21 \\
\end{array}$ & $13.21-15.60$ & $\begin{array}{l}14.32 \\
\pm 0.69 \\
\end{array}$ & $20.56-23.92$ & $\begin{array}{l}22.20 \\
\pm 0.96 \\
\end{array}$ & $8.40-15.78$ & $\begin{array}{l}12.51 \\
\pm 2.17 \\
\end{array}$ \\
\hline Mega feed & $10.29-14.83$ & $\begin{array}{r}12.085 \\
\pm 1.392 \\
\end{array}$ & $8.50-13.30$ & $\begin{array}{r}11.303 \\
\pm 1.442 \\
\end{array}$ & $26.92-30.60$ & $\begin{array}{l}28.714 \\
\pm 2.217 \\
\end{array}$ & $12.69-18.81$ & $\begin{array}{r}15.597 \\
\pm 1.773 \\
\end{array}$ \\
\hline Soudi Bangla feed & $13.58-14.80$ & $\begin{array}{l}14.34 \\
\pm 0.38 \\
\end{array}$ & $12.28-16.25$ & $\begin{array}{l}14.47 \\
\pm 1.96 \\
\end{array}$ & $24.88-29.46$ & $\begin{array}{l}26.54 \\
\pm 1.04 \\
\end{array}$ & $11.76-14.18$ & $\begin{array}{l}13.35 \\
\pm 0.79 \\
\end{array}$ \\
\hline ACI feed & $11.36-12.12$ & $\begin{array}{l}11.812 \\
\pm 0.233 \\
\end{array}$ & $8.35-10.12$ & $\begin{array}{c}9.392 \\
\pm 0.532 \\
\end{array}$ & $26.75-29.83$ & $\begin{array}{l}27.546 \\
\pm 1.201 \\
\end{array}$ & $19.29-23.59$ & $\begin{array}{l}21.609 \\
\pm 1.252 \\
\end{array}$ \\
\hline Fresh feed & $19.76-20.53$ & $\begin{array}{l}20.053 \\
\pm 0.239 \\
\end{array}$ & $15.83-18.60$ & $\begin{array}{l}16.940 \\
\pm 0.845 \\
\end{array}$ & $20.14-25.60$ & $\begin{array}{l}23.103 \\
\pm 1.026 \\
\end{array}$ & $10.13-12.66$ & $\begin{array}{l}11.492 \\
\pm 0.734 \\
\end{array}$ \\
\hline Biswas feed & $11.59-12.28$ & $\begin{array}{l}11.931 \\
\pm 0.199 \\
\end{array}$ & $8.93-9.28$ & $\begin{array}{c}9.123 \\
\pm 0.101 \\
\end{array}$ & $27.07-30.76$ & $\begin{array}{l}28.707 \\
\pm 1.085 \\
\end{array}$ & $14.05-16.97$ & $\begin{array}{l}15.439 \\
\pm 0.845 \\
\end{array}$ \\
\hline
\end{tabular}




\section{Discussion}

In the study area it was found that most of the farm owners are young belongs to the age group range of $20-30$ years (35\%) where $15 \%$ were related to fish culture belongs to the age group 50-60 years which is very much similar to Hossain (2007). Educational status of the fish farmer plays a vital role for the proper management and utilization of the new technology. About $12 \%$ of the total men power are illiterate but had the ability of signature. About $70 \%$ of the men power had primary and high school education respectively. About $14 \%$ and $4 \%$ manpower of the farm had SSC to HSC and Graduate level education, respectively. Quddus et. al. (2000) stated that educational levels of the pond farmers in Demra, Dhaka was below 43\% in SSC, below 38\% in Bachelor and above were $19 \%$ respectively. About $30 \%$ of farm owners having single ownership, $15 \%$ having multiple ownership and $65 \%$ having leased water body. It is evident from many studies that multiple ownership is one of the main problems to improve the management of culture system as well as efficient use of resource for fish cultivation (Ali and Rahman, 1986 ; Mollah et al. 1990).

In the study area about $80 \%$ of the water bodies were irregular shaped due to tectonic origin and $20 \%$ water bodies were regular. The minimum size of the pond was 0.162 ha and maximum size of the pond was 37.247 ha where as the average pond size was 5.78 ha. Bangla pedia (2006) stated that the topography of the area was rough and irregular. The minimum size of the water bodies were 0.06 ha. and maximum size of the water body was 7ha. Ali et al. (2008) stated that an average pond size was 0.13 ha with single (64\%) and multiple ownerships (36\%). According to Islam (2005) average pond size was 0.16 ha (40 decimals) with a range from 0.04 ha (11decimals) to 0.81 ha (200 decimals).

During the study period water quality of different ponds was measured. It was found that the temperature ranges from 14 to $32^{\circ} \mathrm{C}$, $\mathrm{pH}$ ranges from 7.7.-8.5, transparency ranges from $23-45 \mathrm{~cm}$ and the dissolve oxygen ranges from 3.8-6.12 mg. $\mathrm{L}^{-1}$. Similar works have been done by Rahman et al. (1982) measured $25.05-32.89^{\circ} \mathrm{C}$ and $26.5-32.22{ }^{\circ} \mathrm{C}$ for surface and bottom temperature respectively. They recorded DO with a range of $0.40-8.60 \mathrm{mg} / 1$. Wahab et al. (1995) recorded the water temperature varied between 27.2 to $32.4^{\circ} \mathrm{C}$, secchi depth between 26 and $50 \mathrm{~cm}, \mathrm{pH}$ was always around 6.0 and dissolved oxygen was always low varied between 2.2 to $7.5 \mathrm{mg} / 1$.

It was found that the stocking density of pond was very high. The highest stocking density was $3,90,000 /$ ha and the lowest was $54,340 /$ ha. The average stocking density was found between 1, 40,000 and 1,60,000/ ha. Islam (2005) found that average stocking density to be 17, 370/ha/year and Saha (2003) found average stocking density to be 16,561/ha. NFEP-II (1998) suggested the stocking density about $14,820 /$ ha is suitable.

In the study area feeding rate was different for growing fish and aged fish. In monoculture practice feeding rate were found to be $5-6 \%$ to $6-7 \%$ of fish body weight for small fish, 1$2 \%$ and $2-3 \%$ for large fish. In polyculture feeding rate was found $5-6 \%$ and $6-7 \%$ of fish body weight for small fish, $1-2 \%$ and $2-3 \%$ for large fish. $35.89 \%$ farmer used feeding frequency 1 time/day, $53.85 \%$ used 2 times/day and $10.26 \%$ used 3 times/day. The Department of Fisheries (DoF) 2009 recommended feeding rate is 3-6\% of the total body weight and feeding frequency will be two or three times per day. Hossain et al. (1997) reported the rate of $5 \%$ of total body weight, daily in two to three times.

The ingredients are analyzed and found moisture, lipid, protein, and ash. The highest protein (28.714\%) was found in Mega feed, lipid (16.94\%) found in Fresh feed, moisture (20.053\%) found in Fresh feed and ash (21.61\%) found in ACI feed. 
In case of man made feed the highest production was $31,820 \mathrm{~kg} / \mathrm{ha} / \mathrm{yr}$ where lowest production was $10,157 \mathrm{~kg} / \mathrm{ha} / \mathrm{yr}$ with an average production of $23,520 \mathrm{~kg} / \mathrm{ha} / \mathrm{yr}$. The farm where company feed was used the highest production was recorded to be 56,810 $\mathrm{kg} / \mathrm{ha} / \mathrm{yr}$ and the lowest production was $14,210 \mathrm{~kg} / \mathrm{ha} / \mathrm{yr}$ with an average production $34,350 \mathrm{~kg} / \mathrm{ha} / \mathrm{yr}$. The farmer who used the company feed found the best result. According to Islam (2005) yield of fish production was found to be $2,609 \mathrm{~kg} / \mathrm{ha} /$ year. Rahman (2003) stated that the average production of carp was estimated about 2,925 $\mathrm{kg} / \mathrm{ha} / \mathrm{yr}$. Islam and Dewan (1986) observed in North-West Bangladesh that the average annual yield was $1,025 \mathrm{~kg} / \mathrm{ha}$.

All the previous results are lower than the present study. So, It is indicated that production of the studied area is higher than any other part of the country. Apparently in the present study, overall production was higher to lower on remarkable company feed. Therefore, the result of the study suggested that a good quality of feed with a recommended stocking density is resulted a good production.

\section{CONCLUSION}

The fish culture system is developed in Bhaluka upazilla, Bangladesh which changes the socioeconomic status of the farmers and contributes a remarkable part of inland fish production in Bangladesh. As the fisheries sector plays a vital role in the socio-economic development, opportunity for employment, poverty alleviation of a large number of population and earning foreign currency of Bangladesh the following recommendations should be made to develop fish culture practice. 1. The Government should need to take steps to train up interested farm owners in the area of water quality management; quality feed production; production of good quality seed; fish health management, disease control and management and other farm management techniques; 2 . More research needed to find out a quality feed and feeding frequency with a recommended stocking density. 3 . Control measure should be taken against the indiscriminate use of fertilizers, chemicals, disinfectants, antibiotics, hormones and other toxic substances in the ponds. and 4 . Effective linkage should be developed more between Upazilla fisheries office, NGO and fish pond owners.

\section{REFERENCES}

Ali, M.H. and Rahman, M.I. (1986). An investigation on some socio-economic and technical problems in fish pond culture in two Districts of Bangladesh. Bangladesh. J. Aquacult., 8(1).

Ali, M.H., Hossain, M.D., Hasan, A.N.G.M. and Bashar, M.A. (2008). Assessment of the livelihood status of the fish farmers in some selected areas of Bagmara upazilla under Rajshahi district. J. Bangladesh Agril. Univ. 6 (2): 367374pp.

AOAC International (1995). In: Howritz, W. (Ed.), Official Methods of Analysis, 16th edn. AOAC, Washington, DC. 1018 pp.

Bangla pedia (2006). Asiatic society of Bangladesh, Agroecological zone of Bangladesh. www.baglapedia.org.

BBS (2011). Statical yearbook of Bangladesh, Bagladesh Bureau of Statistics, Statistical division, Government of the peoples of Republic of Bangladesh, Dhaka. 580p.

Bernet, Schmidt D.H., Meier, W., Burkhardt, P., Holm and wahli, T. (1999). Histopathology in fish, Proposal for a protocol to asses aquatic pollution, J. of Fish Dis. 22(1): 25-34.

Chakraborty, B. K. (2009). Aquatic biodiversity of Someswari and Nethai River and Gharia and Nidaya beel of Northern Bangladesh. In: Takumi K. Nakamura (Ed.). Aquaculture Research Progress, Nova Science, Publishers, New York, USA. : 3231-268. 
Malaysian Journal of Medical and Biological Research, Volume 1, No 1 (2014)

DoF. (2009). Department of Fisheries, Ministry of Fisheries and Livestock, Matshya Pakkhya Saranika 13p.

DoF. (2010). Department of Fisheries, Ministry of Fisheries and Livestock, Matshya Pakkhya Saranika pp122-124.

Duncan, D.B. 1955. Multiple range and multiple F-testes. Biometrics 11: 1-42pp.

Hossain, M.A., Ahmed, M. and Islam, M.N. (1997). Mixed culture of fishes in seasonal ponds through fertilizer and feeding. Bangladesh J. Fish. Res., 1 (2):9-18pp.

Hossain, M.M. (2007). Utilization of Mokash beel for Livelihood Management of Local Fishermen and their Socio-economic Conditions. M.S. Thesis, Department of Aquaculture, BAU, Mymensingh. 85p.

Islam, M.S. (2005). Socio-economic status of pond fish farming in some selected areas of Dinajpur district. M.S. Thesis, Department of Fisheries Management, Bangladesh Agricultural University, Mymensingh, 65p.

Islam, M.S. and Dewan, S. (1986). Economics of fpond fish culture in some selected areas of Bangladesh. Bangladesh J. Aquaculture., 8 (1): 57-61pp.

Mollah, A.R., Chowdhury S.N.I. and Habib M.A.B. (1990). Input output relations in fish production under various pond sizes, ownership pattern and constraints. Bangladesh J. Train. Dev., 3(2): 87-101pp.

NFEP-II (1998). Aquaculture manual for literate and semi-literate fish farmers. Northwest Fisheries Extension Project-2, Parbatipur, Dinajpur. 81p.

Quddus M.A., Rahman M.S. and Moniruzzaman, M. (2000). Socio-economic eonditions of the pond owners of Demra, Dhaka. Bangladesh J. Fish. Res., 4(2):203-207pp.

Rahman M.S., Chowdhury M.Y., Haque A.K.M. and Haque M.S. (1982). Limnological studies of four ponds. Bangladesh J. Fish., 2-5(1-2):25-35pp.

Rahman, M.M. (2003). Socio-economic aspects of carp culture development of Gazipur, Bangladesh. M.S. thesis, Department of Fisheries Management, Bangladesh Agricultural University, Mymensingh, 72p.

Saha, M.K. (2003). A study on fish production technology in North-West Bangladesh. M.S. thesis. Department of Aquaculture, Bangladesh Agricultural University, Mymensingh, 71p.

Wahab, M.A., Ahmed Z.F., Islam A. and Rahmatullah S.M. (1995). Effect of introduction of common carp Cyprinus carpio (L) on the pond ecology and growth of fish in polyculture. Aquacult. Res., 26 :619 - 628pp.

Zar, J.H. (1984). Biostatistics: Prentice-Hall, Inc. Englewood Cliffs, New Jersey, USA. 718p.

Asian Business Consortium realizes the meaning of fast publication to researchers, particularly to those working in competitive and dynamic fields. Hence, we offer an exceptionally fast publication schedule including prompt peer-review by the experts in the field and immediate publication upon acceptance. 